On the east side of the valley, perhaps 150 feet above the level of the road at Lie Station, I could distinctly trace this terrace by its hummocks of water-laid sand, and the farmhouses perched on its favourable points. A long series of hamlets on the road to Molde is placed upon it. As an object in physical geography, in its form, its uniform level on both sides of the vale, and its relation to the lakes at the summit-level, this terrace precisely resembles the lowest of the Glenroy terraces as it approaches Loch Laggan. It must, however, be more than twice the level above the sea" (p. 105). Chambers, of course, viewed it as an ancient sea-margin.

The same long terrace was also seen by my colleague, Mr. J. R. Dakyns, in 1872, and described (without reference to Chambers) in the Grological Magazine, 1877, p. 74. "If the terrace is on a level," he says, "with the watershed, and there is certainly no great difference between them, one is irresistibly led to think of the similar case of the parallel roads of Glenroy, and . . . of a gigantic Marjelen See dammed back by ice till it overflowed the summit of the pass at Molmen. It is significant that I could see no trace of terrace or water-mark on the Romsdal side of the pass. There is in the same district a second horizontal mark on the solid rock, several hundred feet higher than the 2000feet one. This, too, seems to correspond with sand-terraces in the recesses of the high glens. . . Here again it is striking that the water-mark should seem to correspond with the level of a watershed."

I myself saw Chambers's striking terrace in 1873 . But I have nothing to add to the observations above quoted, and I make no claim what ever to have my name conrected with them. But I may remark the fact that the little deltas or alluvial cones of the streams, where these cross the terraces, so conspicuously bear reference to the surface of the vanished sheet of water in which they were formed, as to remind one how greatly similar evidence was relied on by Darwin as demonstrating the aqueous origin of the roads of Glenroy. Mr. Hansen's discovery of parallel roads at the head of the Glommen and in Jemtland is very interesting, and I hope he will find time to study and map them in detail.

5I, Lauriston Place, Edinburgh, January 24 Hugh Millek

\section{Meteorological Phenomena}

ON January 4 last, while watching a very bright rainbow with a good secondary from Hoylake racecourse, I observed between the two bows a third, fainter than either, touching the primary at the base and extending upwards in such a way that probably, had it all been visible, it would have touched the secondary at the vertex. It was not all visible because of a break in the clouds. Its colours were in the same order as those of the primary, red outside. This third bow was only visible at one side; but a gentleman who observed it stated that he had seen it before, and symmetrical on both sides, though not extending to the vertex.

Another phenomenon I have observed here some time ago. A fall of hail lasting a few minutes occurred, the hailstones being exact cubes, of size about $7 \mathrm{~mm}$. and of consistency like lumps of salt.

University College, Liverpool, February $x$ JOHN C. WILLIS

\section{$M$ BARRE DE SAINT-VENANT}

"W"

have now to consider the earlier work of the greatest of living elasticians." Within a fortnight after these words were sent to the press, on January 6, M. de Saint-Venant died at Vendôme. The news of his death will have caused a deep feeling of regret among English mathematicians and physicists, to whom his researches are so well known that they have attained in their own field a classical value. We purpose in this notice to give some brief account of this foremost representative of latter-day French mathematical physicists.

Saint-Venant stood out for the younger mathematicians of the English school, as the link between the past and the present. Intimately related to the great period of French mathematical physics, he had continued to produce down to our own day, and we felt him to be as real a personality as Helmholtz or Thom- son. A younger member of the school of Poisson, Navier, and Cauchy, he had yet lived to "edit" Clebsch. Deputy for Coriolis at the Ecole des Ponts et Chaussées in 1837 , Saint-Venant early received public recognition for his work from Poncelet in his lectures at the Sorbonne in I 840 ; within the next few years he corrected Cauchy's theory of torsion, and saw his correction accepted by the author of the "Exercices des mathématiques." More than forty years afterwards he "edits" what will long remain the standard treatise on elasticity-the annotated French translation of Clebsch. Thus his work is spread without a break across the middle fifty years of our century; he took up elasticity where Poisson had left it-a mathematical theory; he leaves it one of the most powerful branches of mathematics applied to physics and practical engineering; not a small amount of this transformation is due directly to his researches, or indirectly to his influence.

Turning to the personal character of the man, we find in him the essential characteristics of the scholar and the student, the truest modesty, the complete absence of self, the single-minded devotion to his study. SaintVenant, whose researches on elasticity undoubtedly far surpass those of Navier and Clebsch, is yet content to appear as their editor. But what an editing it is! The original text is hidden, disappears, almost as completely as Peter the Lombard's "Sententia" in a mediæval commentary. It is Saint-Venant's notes, appendices, and corrections, which form the value of these works, which make the third edition of Navier's "Leçons" the standard treatise on the strength of materials, and the French translation of Clebsch the foremost work on mathematical elasticity. Nay, he even praises Clebsch for inventing a term in I 862, which he himself had first proposed in the privately distributed lithographed sheets of 1837 ! Ever ready with advice and assistance, perfectly free from jealousy, Saint-Venant was a typical scholar. We had occasion, scarcely six months ago, to apply to him for assistance with regard to some of his earlier work. Within a few days we received a packet containing twenty-three of his memoirs, all carefully corrected, and many annotated. He expressed a lively interest in the progress of the "History of the Mathematical Theories of Elasticity," lending the editor of that work several French lithographed courses which were otherwise inaccessible, and accompanying them by letters which amounted almost to a dissertation on the history of elasticity.

"Je desire, bien cher monsieur, que ces quelques renseignements et documents puissent servir à l'utile travail historique que vous avez entrepris, et dont j'apprendrai avec plaisir la publication ainsi que le nom de l'éditeur. J'en verrais même avec plaisir les épreuves."

Shortly before Christmas we received from SaintVenant corrections for the first three sheets of Dr. Todhunter's ninth chapter, which is devoted to Saint-Venant's earlier work. On January 3 we sent him the remaining proofs of that chapter; a week afterwards we had to mourn the loss of one whose personal kindness had served to intensify the respect raised by his transcendent mathematical ability.

If we examine the leading characteristics of SaintVenant's scientific work we find them marked by an essentially practical character. We find subtlety of analysis combined always with practical physical conceptions. The problems he attacks are those which are physically possible, or of which the solution is an immediate practical need. He smiles good-naturedly over Lamés attempts to solve the terrible problem of an elastic solid in the form of a right-six-face, whose surface is subjected to any system of load. The solution would be a triumph of analysis, but its physical and practical value would in all probability be nil. He chooses instead a real beam, and he obtains a solution which, if it be but approximate, is at least an approximation to reality, and will serve all practical purposes. Saint-Venant never 